Galaxea, JCRS, 1: 89 -95 (1999)

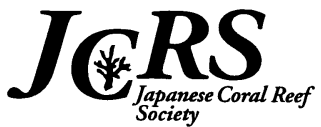

\title{
Coral bleaching, geological ranges, and adaptation to high sea surface temperatures
}

\author{
K. Sugihara ${ }^{1}$, Y. Iryu ${ }^{2}$ and T. Nakamori ${ }^{2}$ \\ ${ }^{1}$ Department of Earth System Science, Faculty of Science, Fukuoka \\ University, Fukuoka, 814-0180, Japan \\ ${ }^{2}$ Institute of geology and paleontology, Graduate School of Science, \\ Tohoku University, Sendai, 980-8578, Japan
}

\begin{abstract}
Coral bleaching was described in Kikai-jima (Kikai Island) in October, 1998. Mortality of coral species belonging to the families Acroporidae and Pocilloporidae was the highest of all scleractinian corals in this island. In contrast, some species of the genera Psammocora and Pavona were never or seldom damaged. These results were similar to those observed in the other Indo-Pacific regions. Significant differences in mortality among families could be attributed to the their geological ranges. The species that were free from appreciable damages by bleaching belong to the families which first appeared in the geological periods when the climate was globally warm (greenhouse periods).
\end{abstract}

Key words: coral bleaching, Kikai-jima, tolerance, high seawater temperature, first appearance

\section{INTRODUCTION}

Mass bleaching and high mortality of corals have been reported from major Indo-Pacific reef provinces since the 1997-1998 ENSO (El Niño- Southern Oscillation) event (Huerkamp et al. 1998; Jaubert et al. 1998; Obura and White 1998; Teleki et al. 1998; Berkelmans and Oliver 1999). In Japan, the coral bleaching corresponding to this ENSO event was first noticed in the shallow lagoon of Ishigaki-jima, Ryukyu Islands (Ryukyus) at the end of July, 1998 (unpublished data). The bleaching extended to the reef slope of this island in August. It was also reported from the other islands, such as Okinawa-jima (Nakano, personal communication) and Kudaka-jima (Nishihira, personal communication) at the beginning to in the middle of August, and Kikai-jima (this study) at the end of August to the beginning of September. This trend clearly shows that the bleaching events gradually spread northward within the Ryukyus.
Scleractinian corals have a symbiotic relationship with zooxanthellae and coral bleaching is recognized as a loss of zooxanthellae and/or their pigments (Glynn 1993; Brown 1997). Gleason (1993) indicated that bleaching events can cause selective mortality and stress on susceptible species. There are many reports which noted differences in the tolerance to bleaching among different coral genera and species (Fisk and Done 1985; Brown and Suharsono 1990; Jokiel and Coles 1990; Gleason 1993; Obura and White 1998; Huerkamp et al. 1998). These differences also arise among neighboring colonies of the same species and even within a single colony (Gleason 1993). Rowan and Knowlton (1995) showed that some coral species can act as hosts of several zoothanthella species, although before this study it was widely accepted that corals harbor only one symbiont. They noted that these zoothanthella species exhibit intra-colony zonation with depth. Based on the relationships between zoothanthella diversity and 
coral bleaching patterns within hosts, Rowan et al (1997) noted that some coral species were protected from bleaching by hosting an additional symbiont that was more tolerant of high irradiance and temperature.

In this study, we focused on susceptibility and mortality in coral species to the bleaching. We investigated differences in the degrees of bleaching among different coral species in Kikai-jima in October, 1998. We discuss the geological ranges and first appearance of coral families and genera within the geological record, and examine these facts in the light of the 1998 bleaching event. We test the hypothesis that taxa with the longest geological record (i.e., ranges) are more tolerant to coral bleaching than those with shorter ranges. The former may have experienced and survived repeated global warming and thus are more adapted to high water temperatures, and hence coral bleaching, than the latter with shortest geo- logical ranges.

\section{METHOD}

The Ryukyus are situated to the southwest of mainland Japan, where the climate is subtropical. Our study site, Kikai-jima, is located in the northern part of the Ryukyus (Fig. 14). The annual mean atmospheric and surface water temperature around this island are 21.5 ${ }^{\circ} \mathrm{C}$ and $24.4^{\circ} \mathrm{C}$, respectively (Iryu et al. 1995). This island is rimmed by raised Holocene coral reefs (Hanzawa 1935; Konishi et al. 1974; Nakata et al. 1978; Ota et al. 1978; Sasaki et al. 1998; Webster et al. 1998) and the presentday reefs.

Veron (1992) discriminated three major faunal groups of hermatypic corals within the Ryukyus; they are, from south to north, Yaeyama, Okinawa, and Amami Groups (Fig. 1-A). He pointed out that species diversity of

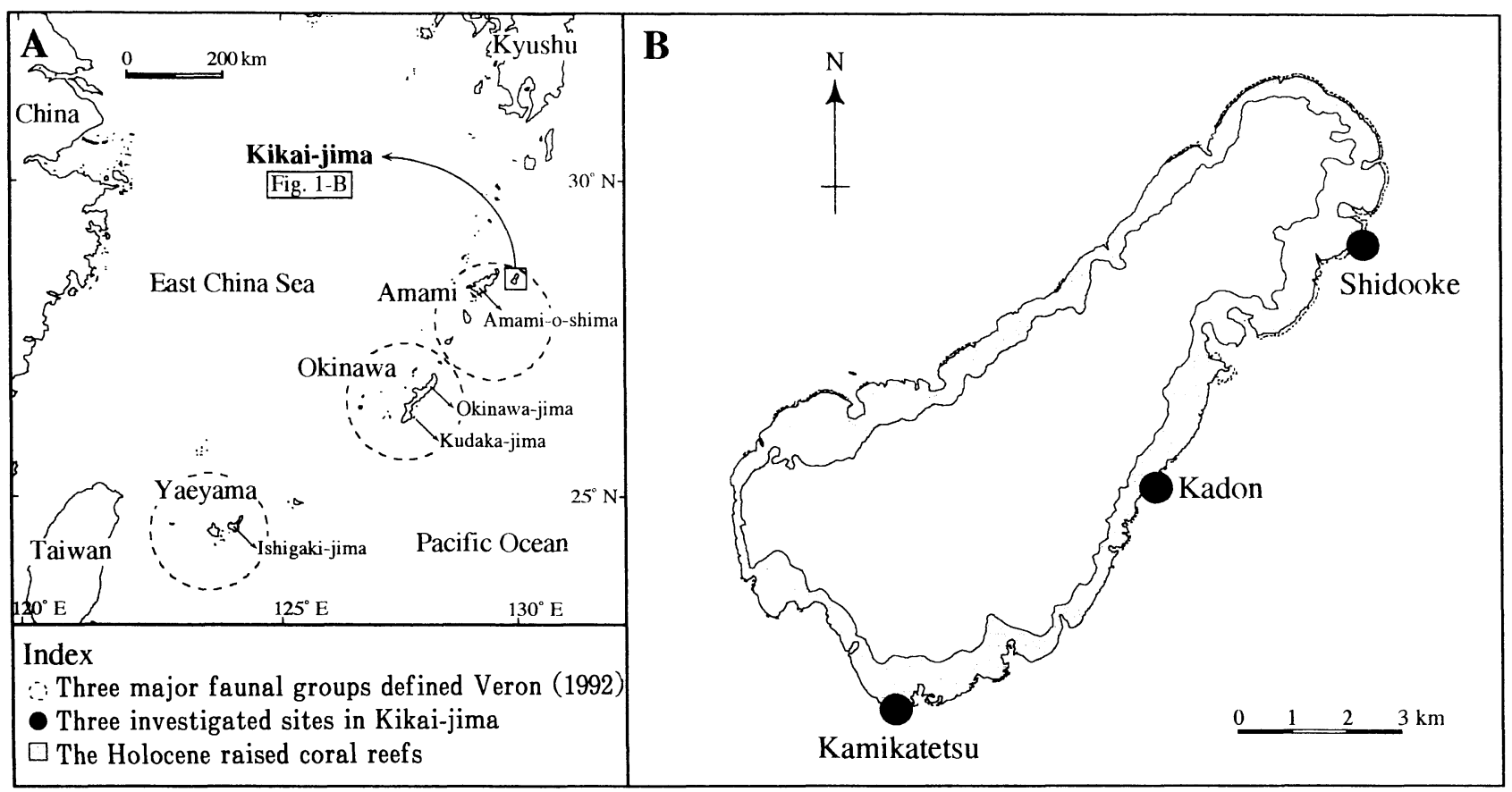

Fig. 1 Map showing the location of the study site within Kikai-jima, Ryukyu Islands

corals decreases with increasing latitude. Kikai-jima belongs to the Amami group, where 220 hermatypic coral species were reported.

Three sites (Shidooke, Kadon, and Kamikatetsu) were investigated on the modern reefs of Kikaijima in order to describe the coral bleaching event in October, 1998 (Fig. 1-B). We recorded hermatypic coral species and their conditions within the study sites from the tide pools on the shore, to the shallow part of reef slope (0-5 m deep) by snorkeling. The investigated areas on the shallow reef slope at each site were set up with a $50 \mathrm{~m}$ rope. A tide pool whose area is approximately $5 \times 10 \mathrm{~m}^{2}$ was investigated at Shidooke site. Two smaller pools (about 2.5 $\left.\times 5 \mathrm{~m}^{2}\right)$ and one bigger pool $\left(10 \times 25 \mathrm{~m}^{2}\right)$, which 
might be formed by fusion of three small ones, were observed at Kadon and Kamikatetsu site, respectively. We counted numbers of coral colonies belonging to 31 species under 14 genera, and recorded their tolerance of bleaching. A total of 624 colonies greater than $10 \mathrm{~cm}$ in diameter were selected to compare the differences in the susceptibility among adult colonies. The corals were grouped into four categories based on their tolerance of bleaching: 1) All or most of colonies were dead from bleaching and covered with filamentous algae; 2) Whole colonies were bleached but soft tissues were still alive; 3 ) Colonies were more or less bleached and the degree of bleaching was different among neighboring colonies, and within a single colony of the same colonies; and 4) Few or none of the colonies were damaged by the bleaching.

\section{RESULTS}

A total of 107 species under 34 genera were recorded at the three sites (Appendix). Neither species composition nor their habitats were different among the three sites. In the tide pools, Montipora digitata and Pavona decussata were the most dominant corals, ass ociated with Pocillopora damicornis, Montipora hispida, Montipora aequituberculata, Acropora microphthalma, Porites spp., Goniopora spp., and Psammocora contigua. Pocillopora verrucosa,

Table 1 Differences in the tolerance to bleaching among major coral species in Kikai-jima, Ryukyu Islands. Four types of bleaching were recognized: 1) All or most of the colonies were completely dead and covered with filamentous algae; 2) Whole colonies were bleached but soft parts were still alive; 3) Colonies were more or less bleached and the degree of bleaching was different from colony to colony and within a single colony; and 4) Few or none of the colonies were damaged. Abbreviations, TP and SRS, indicate the tide pool and shallow reef slope, respectively

\begin{tabular}{|c|c|c|c|c|c|}
\hline Family & Genus & Species & Number of colonies & Type of bleaching & Habitat \\
\hline \multirow[t]{3}{*}{ Pocilloporidae } & Pocillopora & P. damicornis & 12 & 1 & $\mathrm{TP}$ \\
\hline & & $P$. verrucosa & 78 & 1 & SRS \\
\hline & & P. eydouxi & 10 & 1 & SRS \\
\hline \multirow[t]{11}{*}{ Acroporidae } & Montipora & M. digitata & 68 & 3 & $\mathrm{TP}$ \\
\hline & & M. hispida & 10 & 2 & $\mathrm{TP}$ \\
\hline & & M. aequituberculata & 34 & 2 & $\mathrm{TP}$ \\
\hline & Acropora & A. palifera & 44 & 2 & SRS \\
\hline & & A. monticulosa & 28 & 1 & SRS \\
\hline & & A. gemmifera & 16 & 2 & SRS \\
\hline & & A. digitifera & 22 & 2 & SRS \\
\hline & & A. microphthalma & 12 & 1 & $\mathrm{TP}$ \\
\hline & & A. pulchra & 24 & 2 & $\mathrm{TP}$ \\
\hline & & A. tenuis & 8 & 1 & $\mathrm{TP}$ \\
\hline & & A. hyacinthus & 26 & 3 & SRS \\
\hline \multirow[t]{5}{*}{ Poritidae } & Porites & P. lobata & 6 & 3 & TP and SRS \\
\hline & & P. australiensis & 14 & 3 & $\mathrm{TP}$ \\
\hline & & P. lutea & 4 & 3 & TP and SRS \\
\hline & & P. cylindrica & 12 & 3 & $\mathrm{TP}$ \\
\hline & Goniopora & G. tenuidens & 24 & 2 & TP and SRS \\
\hline \multirow[t]{2}{*}{ Siderastreidae } & Psammocora & $P$. contigua & 12 & 4 & $\mathrm{TP}$ \\
\hline & & P. digitata & 4 & 4 & TP \\
\hline \multirow[t]{3}{*}{ Agariciidae } & Pavona & P. decussata & 42 & 4 & $\mathrm{TP}$ \\
\hline & & P. minuta & 10 & 4 & SRS \\
\hline & & $P$. venosa & 14 & 4 & $\mathrm{TP}$ \\
\hline \multirow[t]{7}{*}{ Faviidae } & Favia & F. speciosa & 16 & 3 & TP and SRS \\
\hline & Favites & F. abdita & 18 & 3 & TP and SRS \\
\hline & Goniastrea & G. retiformis & 22 & 2 & SRS \\
\hline & Platygyra & P. daedalea & 9 & 3 & SRS \\
\hline & Montastrea & M. curta & 14 & 3 & SRS \\
\hline & Cyphastrea & C. serailia & 5 & 4 & $\mathrm{TP}$ \\
\hline & Echinopora & E. gemmacea & 6 & 4 & $\mathrm{TP}$ \\
\hline
\end{tabular}


tabular to encrusting forms of Acropora ( $A$. palifera, A. monticulosa, A. gemmifera, and A. hyacinthus), and massive to encrusting faviid corals (Favites abdita and Goniastrea retiformis) dominated the shallow part of the reef slope.

Table 1 shows the differences in susceptibility to bleaching among major coral species. There appeared to be no differences in damage caused by bleaching between in the tide pools and on the shallow reef slope. Pocillopora damicornis, Pocillopora verrucosa, Acropora monticulosa, Acropora microphthalma, and Acropora tenuis were included in Type 1.

Montipora aequituberculata, Acropora palifera, Acropora pulchra, Goniopora tenuidens, and Goniastrea retiformis were characterized as Type 2. Type 3 encompasses Montipora digitata, Acropora hyacinthus, massive form of Porites spp., Porites cylindrica, Favia speciosa and Favites abdita. Psammocora contigua, Pavona decussata, Pavona minuta, Cyphastrea serailia and Echinopora gemmacea were not, or seldom, bleached, and thus were included in Type 4.

\section{DISCUSSION AND CONCLUSIONS}

Mortality of pocilloporid and acroporid corals was the higher than other coral species observed at Kikai-jima. Especially, Pocillopora damicornis, $P$. verrucosa, and $P$. eydouxi were dead at a higher rate. Such a high mortality for Pocillopora species has been previously reported during bleaching events in other IndoPacific regions (Fisk and Done 1985; Jokiel and Coles 1990; Brown and Suharsono 1990; Gleason 1993; Huerkamp et al. 1998).

All Acropora hyacinthus colonies were susceptible to partial bleaching; dead or highly damaged colonies were not found. This is in marked contrast to other Acropora species, all of which were completely bleached. It was reported that $A$. hyacinthus mortality was rather higher than that of other species in the Thousand Islands, Indonesia (Brown and Suharsono 1990) and Moorea, French Polynesia (Gleason 1993). Further investigations are needed to clarify how much $A$. hyacinthus is damaged by bleaching on the different depths and habitats. The degrees of Montipora digitata and Porites spp. bleaching varied considerably from colony to colony. This result is in concordance with those reported by Brown and Suharsono (1990) and Gleason
(1993).

Few of the Pavona minuta colonies and none of the Pavona decussata and Psammocora contigua colonies were damaged at Kikai-jima. Bleaching damage of Pavona venosa and Psammocora digitata was also relatively lower than that of other species. These results may be comparable with low mortality of Psammocora stellata (Glynn 1990) and Pavona gigantea and Pavona clavus (Huerkamp et al. 1998).

Glynn (1993) suggested that scleractinian evolution is concerned with the ability of corals to adapt to various environmental stresses caused by global climatic changes. Bleaching events and an increase in their frequency may be considered as possible indicators of global climatic changes. Coral taxa with longer geological ranges may have experienced and survived such stresses or impacts repeatedly in the past.

From this point of view, we examined the first appearances of coral families in the fossil record. The Pocilloporidae and Acroporidae first appeared in the Late Cretaceous (100 to 67 million years ago). The oldest known occurrences of the Poritidae and the Siderastreidae including Psammocora are mid-Cretaceous (120 to 100 million years ago). The Agariciidae encompassing Pavona and the Faviidae including Favia, Cyphastrea, and Echinopora have been recovered back to Middle Jurassic (170 million years ago) (Wells 1956). Veron (1995) reviewed the fossil records of scleractinian corals based on current taxonomic concepts and gave a new interpretation on their evolution. He noted that the first occurrences of the Siderastreidae and Agariciidae were Late Cretaceous and that Acroporidae extend back to Middle Jurassic. However, he stated that the fossil evidence for the Jurassic origin of Acroporidae was inconclusive and that the extant genera are Cenozoic $(<67$ million years ago) in origin except for Astreopora. It is worth while to note that the families which appeared in the Jurassic (Faviidae) and Cretaceous (Poritidae, Siderastreidae, and Agariciidae) include the modern coral species with a relatively greater tolerance of bleaching caused by high seawater temperature. In contrast, the Acroporidae, "Cenozoic family", encompasses the present-day species comparably less tolerant of bleaching. It is widely accepted that the climate was globally warmer in the Jurassic to Cretaceous than that in Cenozoic (Fisher 1982; Crowley and North 1991; 
Frakes et al. 1992).

Consequently, there exists a possibility that the coral species tolerant of bleaching are included in families whose origins evolved in warmer geological periods.

The odd exception to the rule is the family Pocilloporidae. Although the Pocilloporidae family has its origin in Triassic to lower Jurassic (cool to warm period, Fischer 1982; warm period, Frakes et al. 1992), based on the morphological affinities with the Astrocoeniidae (Veron et al. 1996), the modern Pocillopora species have a low tolerance to bleaching. Here, we should consider that the three major genera within the Pocilloporidae (Pocillopora, Stylophora, and Seriatopora) are distinguished by their long-distance larval dispersion and rafting characteristics (Veron 1995), and thus showing widespread dispersed as dominant genera throughout the Indo-Pacific regions. Such superiority in reproduction might have enabled them to survive the warmer periods by migrating into milder habitats.

At the genus level, there seems to be no re lationships between the coral tolerance to bleaching and their geological records. This is clearly shown by the evidence that the genera Pocillopora, Acropora, Montipora, and Porites have different types of susceptibility to bleaching (Table 1), although their oldest occurrences are Eocene in age (55 to 37 million years ago). However, the first occurrences of many coral genera are not well-determined at present. If the ages are dated more precisely, the first appearances may be concentrated in periods when the climate was globally warmer such as during the early Eocene or early Miocene.

In conclusion, the species in the families Pocilloporidae and Acroporidae showed the highest mortality in the 1998 bleaching event at Kikai-jima, while poritid, siderastreid, agariciid, and faviid species were less damaged; this is a common phenomenon among bleaching events in the Indo-Pacific regions; the differences in the tolerance to bleaching among coral families may be related to their geological ages, and the environmental conditions in which they first appeared.

\section{REFERENCES}

Berkelmans R, Oliver JK (1999) Large-scale bleaching of corals on the Great Barrier Reef. Coral Reefs 18: $55-60$

Brown BE, Suharsono (1990) Damage and recovery of coral reefs affected by El Niño related seawater warming in the Thousand Islands, Indonesia. Coral Reefs 8: 163-170

Brown BE (1997) Coral bleaching: causes and consequences. Coral Reefs 16: S129-S138

Crowley TJ, North GR (1991) Paleoclimatology. Oxford University Press, New York 339 pp

Fischer AG (1982) Long-term climatic oscillations recorded in stratigraphy. In: Berger W (ed) Climate in earth history. National Academy of Sciences, Washington DC pp 97-104

Fisk DA, Done TJ (1985) Taxonomic and bathymetric patterns of bleaching in corals, Myrmidon Reef (Queensland). Proc 5th Int Coral Reef Congr, Tahiti 6: 149-154

Frakes LA, Francis JE, Syktus JI (1992) Climate modes of the Phanerozoic. Cambridge University Press, Cambridge, 274 pp

Gleason MG (1993) Effects of disturbance on coral communities: bleaching in Moorea, French Polynesia. Coral Reefs. 12: 193-201

Glynn PW (1990) Coral mortality and disturbances to coral reefs in the tropical eastern Pacific. In: Glynn PW (ed) Global ecological consequences of the 198283 El Niño- southern oscillation. Elsevier Oceanography Series, Amsterdam pp 55-126

Glynn PW (1993) Coral reef bleaching: ecological perspectives. Coral Reefs 12: 1-17

Hanzawa S (1935) Topography and geology of the Ryukyu Islands. Sci Rep Tohoku Univ, 2nd ser (Geol) 17: 1-61

Huerkamp C, Glynn PG, Ducroz L, Mate JL (1998) Responses of five Eastern Pacific reef building coral species to experimentally elevated temperature. Int Soc Reef Stud Euro Mtg, Perpignan, 1-4 September, Progr Abst, p 96

Iryu Y, Nakamori T, Matsuda S, Abe O (1995) Distribution of marine organisms and its geological significance in the modern reef complex of the Ryukyu Islands. Sediment Geol, 99: 243-258

Jaubert J, Rougerie F, Cadot D (1998) Mass bleaching and mortality of corals in French Polynesia during the 1997-1998 ENSO event. Int Soc Reef Stud Euro Mtg, Perpignan, 1-4 September, Progr Abst, p 97

Jokiel PL, Coles SL (1990) Response of Hawaiian and other Indo-Pacific reef corals to elevated temperature. Coral Reefs 8: 155-162

Konishi K, Omura A, Nakamichi O (1974) Radiometric coral ages and sea level records from the Late quaternary reef complexes of the Ryukyu Islands. Proc 2nd Int Coral Symp 2: 595-613

Nakata T, Takahashi T, Koba M (1978), Holoceneemerged coral reefs and sea-level change in the Ryukyu Islands. Geogr Rev Japan, 51A: 81-108 (in Japanese with English abstract)

Obura DO, White KV (1998) El-Nino related coral bleaching in Eastern Africa, March to May 1998. Int Soc Reef Stud Euro Mtg, Perpignan, 1-4 September, Progr Abst, p 137

Ota Y, Machida H, Hori N, Konishi K and Omura A (1978), Holocene raised coral reefs of Kikai-jima (Ryukyu Islands) - An approach to Holocene sea level study. Geogr Rev Japan, 51A: 109-130（in Japanese with English abstract) 
Rowan R, Knowlton N (1995) Intraspecific diversity and ecological zonation in coral-algal symbiosis. Proc Natl Acad Sci USA 92: 2850-2853

Rowan R, Knowlton N, Baker A, Jara J (1997) Landscape ecology of algal symbionts creates variation in episodes of coral bleaching. Nature 388: $265-269$

Sasaki K, Omura A, Ota Y, Murase T, Azuma T, Kobayashi M, Ikura K (1998) Holocene regressive coral reef terraces at the Northern Shidooke Coast of Kikai Island, Central Ryukyus. The Quat Res 37: 349-360 (in Japanese with English abstract)

Teleki KA, Spencer T, Bradshaw C, Spalding MD (1998) Coral bleaching in the Western Indian Ocean - a sign of the times ? Int Soc Reef Stud Euro Mtg, Perpignan, 1-4 September, Progr Abst, p 176

Veron JEN (1992) Conservation of biodiversity: a critical time for the hermatypic corals of Japan. Coral Reefs 11:13-21

Veron JEN (1995) Corals in space and time: the biogeography and evolution of the Scleractinia. University of New South Wales Press, Sydney 321 $\mathrm{pp}$

Veron JEN, Odorico DM, Chen CA, Miller DJ (1996) Reassessing evolutionary relationships of scleractinian corals. Coral Reefs 15: 1-9

Webster JM, Davis PJ, Konishi K (1998) Model of fringing reef development in response to progressive sea level fall over the 7000 years - (Kikai-jima, Ryukyu Islands, Japan). Coral Reefs 17: 289-308

Wells JW (1956) Scleractinia. In: Moore RC (ed) Treatise on invertebrate paleontology. Coelenterata. Geological Survey of America and University of Kansas Press, pp 328-440

(Dete of acceptance: August 11, 1999)
地質学的観点からみた造礁サンゴ類の白化現象

杉原 薫 ${ }^{1}$ - 井龍康文 ${ }^{2} \cdot$ 中森 亨 $^{2}$

1福岡大学理学部地球圈科学科地学分野

${ }^{2}$ 東北大学大学院理学研究科地圈進化学講座

琉球列島では1998年に大規模な造礁サンゴ類の白化 現象がおこった。われわれは、鹿児島県喜界島におい て白化に対する造礁性サンゴの耐性について詳細に検 討した。その結果、ミドリイシ科のミドリイシ属と八 ナヤサイサンゴ科のハナヤサイサンゴ属の致死率が最 あ高かった。一方、ヤスリサンゴ科のアミメサンゴ属 およびヒラフキサンゴ科のシコロサンゴ属は、白化の 影響をほとんど受けていなかった。これらの結果は、 これまでに他のインド・太平洋地域から報告されてい る結果とよく一致する。このような分類群による白化 への耐性の違いは、各分類群の系統と関連していると 思われる。すなわち、科レベルでは、出現した地質時 代が古いものほど白化に対して強い耐性を有するのに 対し、地質学的に新しい時代に出現したものほどダメー ジが大きいという傾向が読みとれた。また属レベルで は、白化に対して強い耐性を示したもののほとんどが、 地球史の中でも温暖な時期（温室期）に出現した可能 性が大きい。 
Appendix List of hermatypic coral species at the study sites (Shidooke, Kadon and Kamikatetsu), Kikai-jima

\begin{tabular}{|c|c|c|c|c|}
\hline Pocillopora damicornis & Acropora austera & Pavona decussata & Caulastrea furcata & Leptoria phrygia \\
\hline Pocillopora verrucosa & Acropora aspera & Pavona minuta & & \\
\hline Pocillopora meandrina & Acropora pulchra & Pavona varians & Favia pallida & Oulophyllia crispa \\
\hline \multirow[t]{2}{*}{ Pocillopora eydouxi } & Acropora tenuis & Pavona venosa & Favia speciosa & \\
\hline & Acropora selago & & Favia favus & Montastrea curta \\
\hline \multirow[t]{2}{*}{ Seriatopora hystrix } & Acropora hyacinthus & Gardineroseris planulata & Favia rotumana & Montastrea magnistellata \\
\hline & Acropora nana & & Favia maritima? & Montastrea valenciennesi \\
\hline \multirow[t]{2}{*}{ Stylophora pistillata } & Acropora nasuta & Coeloseris mayeri & & \\
\hline & Acropora florida & & Favites chinensis & Leptastrea purpurea \\
\hline Montipora digitata & & Pachyseris rugosa & Favites abdita & Leptastrea transversa \\
\hline Montipora turgescens & Astreopora myriophthalma & Pachyseris speciosa & Favites halicora & \\
\hline Montipora hispida & Astreopora gracilis & & Favites flexuosa & Cyphastrea serailia \\
\hline Montipora informis & & Fungia sp. & Favites complanat? & Cyphastrea microphthalma \\
\hline Montipora aequituberculata & Porites lobata & & Favites pentagona & \\
\hline \multirow[t]{2}{*}{ Montipora sp. } & Porites australiensis & Galaxea fascicularis & Favites russelli & Echinopora gemmacea \\
\hline & Porites lutea & & & Echinopora pacificus \\
\hline Acropora palifera & Porites cylindrica & Acanthastrea echinata & Goniastrea retiformis & \\
\hline Acropora gemmifera & Porites lichen & Acanthastrea hillae & Goniastrea edwardsi & Euphyllia glabrescens \\
\hline Acropora samoensis? & Porites horizontalata & & Goniastrea - & Euphyllia ancora \\
\hline Acropora monticulosa & Porites sp. & Lobophyllia hemprichii & Goniastrea favulus & \\
\hline Acropora digitifera & & Lobophyllia corymbosa & Goniastrea pectinata & Turbinaria frondens \\
\hline Acropora robusta & Goniopora tenuidens & & Goniastrea australensis & Turbinaria reniformis \\
\hline Acropora danai & Goniopora sp. & Symphyllia recta & & \\
\hline Acropora nobilis & & Symphyllia radians & Platygyra daedalea & Millepora platyphylla \\
\hline Acropora grandis & Psammocora contigua & & Platygyra sinensis & Millepora exaesa \\
\hline Acropora formosa & Psammocora digitata & Hydnophora exesa & Platygyra ryukyuensis & Millepora tenella \\
\hline Acropora acuminata & & Hydnophora microconos & Platygyra $\cdot$ pini & \\
\hline Acropora microphthalma & Coscinaraea columna & & Platygyra contorta & \\
\hline
\end{tabular}

